\title{
THE RIVER'S CONTRACT: AN OPPORTUNITY FOR NEW LANDSCAPE PLANNING ACTIVITIES
}

\author{
D. CIALDEA \& S. CACUCCI \\ L.a.co.s.t.a. Laboratory University of Molise, Campobasso, Italy.
}

\begin{abstract}
The River's Contract is a new tool based on the voluntary agreement between local authorities and private people as a form of negotiated and shared planning procedure. It can be an opportunity to achieve landscape quality aims established by the National Code for the Cultural and Landscape Heritage. The River's Contract does embrace protection of main beliefs, 'both because its natural and environmental meanings, both as the artificial landscape, created by people'. This type of approach may be even more significant in the context of inland areas, as areas subject to strong centrifugal forces, with demographic problems and unbalanced development. The 'internal areas', as known characterized by lack of services in the small urban settlement, can promote polycentric solutions aimed at improving the production quality of the sites. As part of the optimization of the relationship between a city and country they can accommodate development models linked to valorization of their natural and cultural heritage, finalized to the maintenance of its territorial identity. This paper aims to investigate the energy potentialities of river flows, in particular regarding the possibility of the hydro-electric plants, that are either unused or underused. They are elements of interest from the point of view of the local technological tradition. Moreover, they can be used following a project in order to create local energy centres, identified through the study of programming wishes expressed by the local authorities.
\end{abstract}

Keywords: land use, landscape planning, river contracts.

\section{INTRODUCTION}

In this paper we analyze contexts along the river flow: the case study is the Biferno River in Molise, a river completely running inside the region and which is the main local invariant of its central area, along with the Matese mountain range from which it arises. Within the preparation analyses for the new Landscape Plan of the Molise Region conducted in the laboratory L.a.co.s.t.a. University of Molise [1], the Biferno River has been the basic element for the identification of different homogeneous geographical areas for the entire Province of Campobasso. The first area is the source of the river, the agricultural flat land with numerous environmental emergencies and characterized by the presence of several agro-fed quality companies; the middle part of the course of the Biferno is characterized by a hilly area of great geological and environmental difficulties and the last level is the Lower Molise characterized by intensive agriculture production and, at the mouth of the river, by the presence of the Industrial Area in Termoli. In this context, the River's Contract may be experienced in the implementation phase of landscape planning, because it could achieve the quality aims established by the Code of Cultural and Landscape Heritage [2], highlighting the features of the places, in correlation to the real needs of the territories and the needs of the inhabitants.

In view of the many land re-qualification projects, principles of the landscape protection take on a specific role especially in light of the territorial connotations of the internal regions, as in the case of the Molise Region. The shared model of territorial choices, aimed at recovering the environments that involve the river flow, must inevitably refer to the landscape connotations of a region seen as sufficiently homogeneous geographical area. 
The isolation is a critical element to ensure adequate quality of life in relation to the difficulties of access to basic services, at the same time allowed to rural areas of the region to maintain environmental features that are fine and follow strong traditions in productive activities. In addition, the weakness of the infrastructure system worsens conditions from the point of view of tourism potential [3, 4].

Within internal areas, the final aim is the landscape quality: "In this context therefore a great opportunity is offered by the "River's Contract", that could be understood as the best "gym" where to exercise and then it can constitute the backbone on which to base the rational development of Inner Areas [5]. Moreover, the River's Contract can be the tool for bringing and collecting the "common feeling" and also for making good policy decisions based also on contrasts and opposing interests, but in the end still shared. If the River's Contract is therefore an important example of environmental management "from bottom", it could be the test to share the Inner Areas planning aims' [6].

Furthermore, in relation to environmental valuable sites, there is a critical condition for inner areas, because of their intermediate physical location which places them neither in the tourism circuits of the upper valleys nor in the lower valleys' industrial development [7].

The inner-land case study is particularly significant because in these areas there are some typical features as hilly and mountainous morphologies, even harsh and dangerous: posing high environmental risks linked to slopes' instability and to waterways' unpredictability; economic marginalization caused by the absence of real estate interests, which are elsewhere concentrated [8].

Therefore, the River's Contract is important not only for respecting environmental qualities but above all for territorial rebalancing, aimed at local development of a strongly characterized agricultural land.

\section{THE RIVER'S CONTRACT FEATURES}

The contract, as a voluntary agreement based on negotiated involvement, has in itself the ability to include a multiplicity of interests that in our examined cases are often a source of conflict, in relation to their physical features and those related to involved actors.

Primary objectives, therefore, are facing the need to make the system of these 'interests' in order to recovery the waterway identity.

The River's Contract could be the way to combine interventions for environmental protection - closely related to the resolution of flood safety problems - with needs of local productive development and fruition. The active involvement of local communities is, therefore, essential for searching for solutions based on integrated policies for ecological regeneration, and for fruition of the landscape river system.

In fact, the River's Contract is an agreement that allows us to 'take a rules system in which criteria of public utility, economic performance, social value and environmental sustainability are involved so equal in searching solutions for the River Basin redevelopment [9].

The spread of the River's Contracts, starting from the first French and Belgian experiences, before moving to the growing proposals in the Italian Regions [10], denotes the growing interest in river issues. It also opens new possibilities for deepening action potentials on decision-making involving the territory and the landscape of the natural and anthropic settlements.

Precisely for this reason, it is interesting to deepen the framework of legislative references that, especially at the European level, confirm interests in environmental issues. The Directive 
2000/60/EC, for the redevelopment of surface and ground water, establishes a framework for Community action in water management, identifying the "Hydrographic Basin"' as the correct territorial unit reference. Article 14 says that 'the success of this Directive relies on close cooperation and coherent action at Community, Member State and local level as well as on information, consultation and involvement of the public, including users' [11].

Further directives are the Habitats Directive 92/42/EEC [12] of the European Ecological Network, or Directive 2007/60/EC on flood risk [10, 13].

In Italy, references concerning landscape issues are the already mentioned Code of Cultural and Landscape Heritage, and the Legislative Decree 152/2006 [14] on environmental issues. It contains 'rules on environmental subject', implementing the Directive 2000/60/EC and repeating the objectives pursuit of prevention and reduction pollution. For this purpose, it provides nationwide division into hydrographic districts and provides the Management Plan for each district.

In our paper, we analyze the Urbani Code in depth, especially because nowadays regions are required to provide for measures aimed at preserving landscape and defining solutions for its utilization, even with specific reference to identification of 'river areas of basins/sub-basins as fields/areas to be regulated by specific measures'.

Therefore, for Italy it is interesting to explore the potentials of the Urban Code incorporating the realization of River's Contracts in the landscape planning applications.

In particular, River's Contracts, as negotiated planning processes, favour the definition of the aims through sharing intentions. In fact, the Law 662/1996 [15] on 'Measures for the rationalization of public finances', art. 2, c. 203 incorporates the negotiated planning issues among agreements able to regulate 'interventions that involve multiple public and private entities and engage institutional decisions and financial resources from National Government, Provinces as well as Local Authorities', particularly describing it as 'regulation agreed by Public Bodies or between the Competent Public Authority and public or private partners for the implementation of various measures, finalized to development purposes, requiring a comprehensive assessment of the activities of competence'.

The contract, therefore, is a 'commitment act, shared by various public and private entities, for various reasons interested in watercourses, for sharing arrangements to pursue environmental rehabilitation and socio-economic regeneration of the river system'.

Finally, the implementation of the National River's Contracts Chart [2] in Italy resulted in a progressive movement of adhesions, by an increasing number of regions. This Chart defines environments related to water courses as 'living landscapes' $[16,17]$ by their 'EU principles of democratic participation in decisions, which constitute the backbone of the recent Treaty of Lisbon'. However, this Treaty underlines that local participatory processes fully grasp 'regional and local dimension', which the European Union intends to investigate through its consultations and its legislative proposals [18].

Negotiated planning also allows us to 'identify territorial retraining able to pursue the so-called "balance of the three E" (Ecology, Fairness, Economy, in Italian Ecologia, Equità, Economia): local communities define the shared measures for the redevelopment of their land $[\ldots]$ without threaten natural, built and social systems on which environmental, social and economic services depend'.

\section{A PROPOSAL FOR THE MOLISE REGION: THE METHODOLOGY APPROACH}

Our proposal aims to check the experimental new 'Ex-Post Methodology' for the analysis of Conditions and Consequences on the environmental and landscape features, through a series 
of 'Sustainability Indicators', based on the analysis of 'Complexity, Resilience and Connexion' elements as part of a landscape evaluation [19-26].

This proposal aims to check our experimental new 'Ex-Post Methodology' for the analysis of conditions and consequences on the environmental and landscape features, through a series of 'Sustainability Indicators', based on the analysis of 'Complexity, Resilience and Connexion' elements [19-26].

We named our methodology as Water Landscape Planning (WLP) for the policentric use of the natural-environmental-economic-social values of the different involved territories.

Moreover, the WLP Methodology was created in order to identify 'Matrices of Indicators', useful for the Landscape Evaluation aspect of the cities and also for all reflections on their whole surrounding territory. It could generate a support for development, transforming the urban and rural areas to attractive areas for living and working. Through a cognitive investigation as well as for the definition of a methodology for safeguard, valorization and usability of these areas, the project conveys to a conscious perception of the water heritage in areas involved in watercourses [19-21]. The main activities carried out are local investigations in order to reach the proposed aims.

It is obvious that the rivers course across different territorial situations: our aim is to find the values connected to the environment and to the production factors for each unit. Most of these situations are diverse because of their natural asset and because of the presence of infrastructures passing through them which determines different economical conditions.

The fulfilment is a common policy for heritage restoration using also eco-compatible tools for the landscape and its resources.

Closely linked to this main objective - that is the Strategy for Water Landscape Evaluation - is the creation of a database containing indicators oriented to improving the water quality through measures that benefit natural habitats, support public recreation, and enhance waterfront and upland communities in order to identify and pursue strategies to increase the city's resilience to climate change.

The WLP Methodology can be implemented by these following phases:

1. Elementary Data Collation: Natural Resources, Visual Impacts, Agriculture Activities, Tourism Activities.

2. Selection of Indicators: especially related to agricultural uses and tourism services.

3. Creation of the Model: creation of a model for sustainable and eco-compatible development aimed at enhancing the quality of areas under study. The model will be applied to the realities of the areas involved and will be a tool available to local agencies and operators.

4. Periodic Distribution of Information: production of periodic reports on research results.

5. Implementation and Management of Web Site and Forum: information technology with differentiated aperture on the one hand for project participants and, on the other hand, for operators within the sector.

6. Fruibility of the Model: extension and aperture of the model for further updates, which will be directly usable by local operators and agencies.

Moreover, the WLP Methodology was implemented during the progressive analyses, identifying accurate needs noticed in various sites: the different territorial localities, in fact, have problems and lacks atypical from each other.

We analyzed in particular memories of the river culture, constituted by simple and complex buildings, strictly linked to productive activities that need power water. The risks, 
therefore, are multiple: the risk of the lack of 'landscape' memories; the lack of the 'memory' of lifestyles and social conditions; the lack of the traditional buildings linked to river exploitation; the lack of the economic resources due to the modernization of the activities.

We emphasize not only the exploitation of the landscape settlement resources, but also the enhancement of production activities linked to landscape features maintenance, because it can constitute a valid contribution for the valorization of a common local identity. The data collection, in fact, includes information regarding production uses and environmental features; the definition of a strategy for the valorization of the surviving heritage linked to production activities and the creation of tourism-cultural itineraries, which will highlight peculiarities of each area. This plan differs from others because it evidences not merely one aspect of territorial reality, but - through the integrated management model - will be able to compare naturalistic and human heritage and provide evidence of the best solution for land valorization in different situations, in particular through the creation of a specific software. The final aim of the programme is to provide a useful tool that is also easy manageable by scientists and by anyone who would like to use it. It will be an element available to local agencies as reference for new proposals.In conclusion, our aim was related to the dictates of the European Documents already mentioned: in fact, this project aims to highlight the needs of economic and social renewal, and an improvement for local authorities activities. The creation of a software useful for local authorities for the management of natural and cultural resources falls within the priorities announced by the Lisbon Strategy. Moreover, the improvement of contextual conditions, especially environmental ones, plays an important rule within the new strategies for European Territorial Cooperation. In line with the principles of the Gothenburg Agenda, the project also aims to contribute to the purpose of sustainable development. The Gothenburg European Council, in fact, completed the Lisbon strategy by adding the environmental dimension, 'focussing on a new emphasis to protect the environment and achieve a more sustainable pattern of development' [27].

Project's spirit returns to one of the main project priorities of territorial cooperation with the objective of rendering places attractive for living and working. The cultural values of involved river surroundings would be valorized for tourist development, linked to the nature of architectural structures and to the values of the environment. Moreover, the project aimed to protect landscape features with the growth of the wellness, oriented to sustainable development. The Environmental Action Strategy for Sustainable Development [28] in Italy shows the priority of territorial rebalance, which reduces the use of natural capital and promotes optimal management of the physical resources and quality of urban and rural settlements in environmental sustainability logic. Regions in their Rural Development Plan - as the Molise Region done [4] - develop the priority target of protection and improvement of appeal of rural territories with the redevelopment of human elements and the valorization of cultural heritage.

Anyway, in our case study, we have identified areas of the Biferno basin. As shown in Fig. 1, there are three sub-areas: the Source Zone, the Central Molise area and the Mouth Zone.

1. The Biferno Source Zone

The Biferno source is in a flat area with agricultural activities running along the Matese Mountainous Chain, where many environmental emergencies are inserted. The area is also renowned for many quality agro-food productions, mainly related to the dairy industry and is one of the major regional tourist attraction areas. In fact, winter tourism 


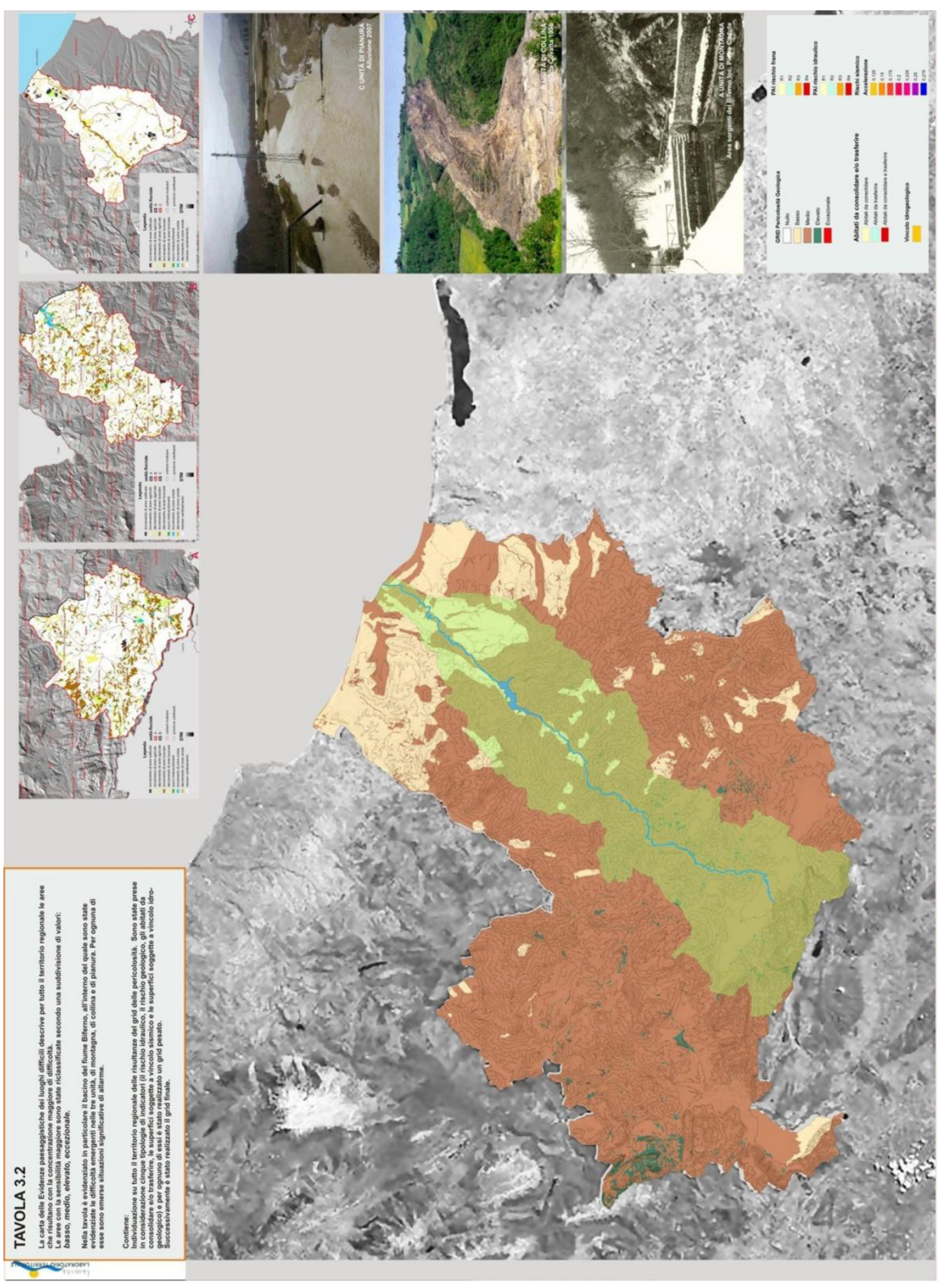

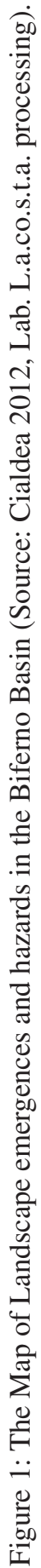


(especially in Campitello Matese) is famous and also environmental tourism (Guardiaregia-Campochiaro WWF Oasis and the Matese Mountains) [29].

2. The Central Molise area

This area is characterized by the presence of hydroelectric plants. Actually, the whole area is not within any Landscape Plans. In the definition of new borders for the New Regional Landscape Plan, this part of the Biferno basin lies in two areas 'Right Biferno' and 'Left Biferno', because of their different features in the two riversides. Only the artificial Guardialfiera Lake - Liscione Dam area falls, almost entirely, in the Actual Landscape Plan No.2. It is characterized by the presence of a large IBA area of about 45,000 hectares and numerous SCI and SPA related to the ecosystem of the lake [30].

3. The Biferno Mouth Zone

The area of the estuary is characterized by the presence of SCI named 'Mouth of the Biferno - Campomarino Coast' (IT722216) and also by the presence of the Industrial Zone of Termoli.

The SCI area is developed for 816.93 ha. along the coastal area near the mouth of the Biferno and includes the entire coast of Campomarino.

This SCI presents, at the same time, extremely interesting naturalistic and anthropic phenomena, heavily reflecting on the protected ecosystem.

Again, in fact, a heavy environmental detractor is the touristic Port of Campomarino, which with its structures radically altered sedimentary processes along the coast.

This change in the distribution of sediments affected a significant retreat of the coastline with the loss of a long stretch of beach and dunes. In some areas, south of the port infrastructure, the beach is reduced to less than $5 \mathrm{~m}$, and trees of the historical pine forest are directly exposed to destructive storm surges.

Another negative factor affecting the ecosystem of this area is related to building expansion phenomena, especially in the southern part of the urban settlement of Campomarino Lido. Often during excavation work to build new districts, dunes were totally and irrevocably destroyed [31, 32].

\section{CONCLUSIONS}

In conclusion, our analyses define some actions activities oriented to the creation of the Biferno Park, through the realization of different sub-areas localized in zones from the point of view of identitifying local communities and useful for landscape sustainability along watercourses and their riversides. However, these actions tend to consolidate the productive asset and to promote its evolution through the involvement of local and regional governments. Maps created will be able to define values useful for the River's Contract because they try to explain the approaches to relevant issues and the endogenous development strategy requirements. The main issues are:

1. Agriculture, that is the essence of the most past of the Biferno River Basin.

2. Naturalness and biodiversity, as reflecting the intensity of human interventions on ecosystems.

3. Ecological Network, as it is oriented to high conservation value.

4. Green Paths and the Blue Ways, because the Biferno Valley is characterized by historical tracks, that are "tratturi", and waterways.

5. Rehabilitation of old plants electricity producers. 
6. Creation of circuits of small towns and rural villages, such manned sites, as cultural and archaeological attractors along the valley.

7. Planning Purposes related to improvement and qualification (in terms of sustainability) of activities.

8. Incentives related to actions as provided for the Rural Development Plan.

Each of these eight issues was analyzed, on spatial and time trends, in relation to the three already mentioned matrices: Complexity, Resilience and Connexion.

The methodological model, developed to analyze landscape transformation processes, involves matrices indicators related to natural, environmental, social and economic features. In particular, they are three matrices for evaluation of the level of complexity, resilience and connexion.

The complexity of a landscape-environmental system is measurable in relation to flows, both internal and external, to the system itself. Complexity in landscape can be read as the balance between the natural resources maintenance and settlement features of the site, maximizing those which are aimed to satisfy basic needs and improve social equity.

The second dimension is the resilience. Each modification of the balance between the settlement-economic system and the natural-environmental system, determines a landscape evolution. Much more the landscape system is complex, the ability to resilience to transformation processes growth, determined mainly by changes of land use. Resilience is a factor useful for understanding sustainability, because it is "the capacity of a system to absorb disturbance, undergo change and still retain essentially the same function, structure, identity, and feedbacks".

The third analyzed category is the Connexion, in relation to landscape fragmentation. Changes in land use generated alteration of landscape traditional units, very often reducing the territory in spots without connection with the surrounding tissue. Connexion, therefore, may be an indicator for the evaluation of the intergrity of a landscape.

River's Contracts are becoming a new land connotation not only linked to the conservation of biodiversity and the protection of the environment but also to their ability to ensure sustainable local development, in compliance with various local identities of the surrounding territories.

In this they can be an opportunity for the development and the growth because it could be able to intercept the increasing requests for green tourism.

This project, localized within the river basin, can contribute not only to safeguard the environment and the health of populations, favouring its careful utilization, but also to create the possibility to recover old paths, that can be restored as greenways to slow mobility, and historical buildings along them can be used by a sustainable tourism.

Particular attention has been paid to the transformation of agricultural landscape through an integrated approach to the analysis of the functions that the environmental and cultural resources, such as the ancient road infrastructure - both natural and artificial - have in the process of development of rural areas, taking care to identify compatible uses as well as the factors that could impact them [33-35].

This study shows a scenario of strong transformation of landscape along a river course, for which it is necessary, in conclusion, to reconsider the policy of conservation and management according to new standards in the landscape quality aims.

\section{REFERENCES}

[1] Regione Molise, Agreement with the 1.a.co.s.t.a. Laboratory (Director prof. D. Cialdea) of the University of Molise for the realization of the "New Regional Landscape Plan of Molise”, signed 11.02. 2011. 
[2] Regione Lombardia, Regione Piemonte, Autorità di Bacino del fiume Po, A21 Italy Contratti di fiume, Carta nazionale dei Contratti di fiume, 2010.

[3] Decreto legislativo 22 gennaio 2004, n. 42 Codice dei Beni Culturali e Paesaggistici ai sensi dell'art. 10 della Legge n. 137 del 6 luglio 2002 (G.U. del 24 febbraio 2004) as amended and integrated.

[4] Italy, Rural Development Regional Programme, Molise 2014-2020.

[5] Italy, National Internal Areas Strategy (SNAI) in relation to the integrated approach to territorial development set out in Article 15 paragraph 2 letter a) of EU Regulation. $1303 / 2013$.

[6] Roberto Minervini, Il Contratto di Fiume Paglia quale asse portante di una Strategia Progettuale per le "Aree Interne" in Umbria, IX Tavolo Nazionale dei Contratti di Fiume, Venice 18 and 19 November 2014.

[7] Federica Corrado, Nuove forme dell'abitare nelle terre alte e produzione di territorio in Atti della XVII Conferenza nazionale SIU, L'urbanistica italiana nel mondo, Milano 15-16 maggio 2014, Planum Publisher, Roma-Milano, pp. 941-946, 2014.

[8] Fabrizio Esposito, Ingegneria \& Paesaggio in Liguria. Una proposta per una possibile integrazione in Atti della XVII Conferenza nazionale SIU, L'urbanistica italiana nel mondo, Milano 15-16 maggio 2014, Planum Publisher, Roma-Milano, pp. 962-969, 2014.

[9] $2^{\circ}$ World Water Forum on the Water, L'Aja, 2000.

[10] Massimo Bastiani, edited by, Contratti di fiume: pianificazione strategica e partecipata dei bacini idrografici, Palermo, D. Flaccovio Editor, 2011.

[11] Directive 2000/60/EC of the European Parliament and of the Council of 23 October 2000 establishing a framework for Community action in the field of water policy, Official Journal of the European Communities 22.12.2000.

[12] Habitats Directive 92/42/EEC of the European Ecological Network.

[13] Directive 2007/60/EC of the European Parliament and of the Council of 23 October 2007 on the assessment and management of flood risks, Official Journal of the European Union 6.11.2007.

[14] Decreto legislativo 3 aprile 2006, n. 152 Norme in materia ambientale (G.U. n. 88 del 14 aprile 2006).

[15] Legge 23 dicembre 1996, n. 662 Misure di razionalizzazione della finanza pubblica (G.U. n. 303 del 28 dicembre 1996).

[16] Jønch-Clausen, T. \& Fugl, J., Firming up the conceptual basis of integrated water resources management. Water Resources Development, 17(4), pp. 501-510, 2001. http://dx.doi.org/10.1080/07900620120094055

[17] World Water Council, Integrated water resource management: a new way forward. A Discussion Paper of the World Water Council Task Force on IWRM, 2015.

[18] Treaty of Lisbon amending the Treaty on European Union and the Treaty establishing the European Community, signed at Lisbon, 13 December 2007, Official Journal of the European Union, C 306, 17 December 2007 and Consolidated versions of the Treaty on European Union and the Treaty on the Functioning of the European Union, Official Journal of the European Union C 326, 26/10/2012.

[19] Cialdea, D. \& Mastronardi, L., A multi-criteria methodology oriented to the preservation of the coastal areas landscape. In (a cura di) Proceedings of the 5th International Conference on Development, Energy, Environment, Economics (DEEE '14), eds F. Batzias, N. Mastorakis \& C. Guarnaccia, WSEAS Press, ISBN: 978-960-474-400-8, pp. 237-243, 2014. 
[20] Cialdea, D. \& Mastronardi, L., Integrated approach in the planning stage for landscape conservation in the coastal italian areas. International Journal of Design \& Nature and Ecodynamics, 9(4), pp. 296-306, 2014. http://dx.doi.org/10.2495/DNE-V9-N4-296-306

[21] Cialdea, D., The landscape features in the urban context. Sustainable Strategies for the small town in the South of Italy. In: (a cura di): Aspa Gospodini. Proceedings of the International Conference on Changing Cities II. Spatial, Design, Landscape \& Socioeconomic dimensions, Thessaloniki Grafima Publ., ISBN: 9789606865886, pp. 169-179, 2015.

[22] European Commission, Establishing a framework for maritime spatial planning and integrated coastal management, Bruxelles, 2013.

[23] Worm, B. et al, Impacts of biodiversity loss on ocean ecosystem services. Science, 314, pp. 787-790, 2006.

http://dx.doi.org/10.1126/science.1132294

[24] UNEP, Mediterranean Action Plan, Ecosystem Approach in the Mediterranean, Paris, 2013.

[25] MATT, Italian National Report on the implementation of ICZM based on the EU, 2012.

[26] EUCC, The Coastal Union 2006. Measuring Progress in the Implementation of Integrated Coastal Zone Management: Guidelines for Completing the Progress Indicator. EU Working Group on Indicators and Date, 2006.

[27] Gothenburg Strategy, first EU Sustainable Development Strategy, adding an environmental dimension to the Lisbon process for employment, economic reform and social cohesion, 2001 as amended and integrated.

[28] Ministry for the Environment and Territory, Environmental Action Strategy for Sustainable Development in Italy, 2015.

[29] Alessandra Maccarone, Governo del Territorio e Mobilità Urbana Sostenibile: la Metropolitana Leggera Matrice-Campobasso-Bojano, A. I. S. Re. - Associazione Italiana di Scienze Regionali - XXXV Conferenza scientifica annuale, Uscire dalla crisi. Città, Comunità e Specializzazione Intelligenti, Padova, 11-13 settembre 2014.

[30] Cialdea, D., Ancient Territories and New Scenarios, Opening of the Academic Year 2010-2011 University of Molise, October 4th, 2010.

[31] Cialdea, D., Il paesaggio tra infrastrutture e dissesti. Un'analisi territoriale applicata alla regione Molise. In AA.VV. Edilizia rurale e paesaggio agrario tra passato e futuro, Firenze, Alinea Editrice, ISBN 978-88-6055-402-4 pp. 29-34, 2009.

[32] Nicola Cacchione, Una cartografia tematica delle unità di paesaggio individuate nelle realtà ambientali del Molise, Thesis PhD Corse Analisi e valorizzazione del Paesaggio XX Ciclo Università del Molise, 2008.

[33] Cialdea, D., A new landscape planning approach to areas with a strongly rural matrix. In Planning Support Tools Policy Analysis, Implementation and Evaluation, eds M. Campagna, A. De Montis, F. Isola, S. Lai, C. Pira \& C. Zoppi, Milano, Franco Angeli Editore, pp. 453-464, 2012.

[34] Cialdea, D, Mastronardi, L. \& Giannelli, A., Data-tourism spatialization: a new methodology useful for landscape planning assessment. In 5th Central European Conference in Regional Science International Conference Proceedings, eds P. Nijkamp, Kosice Technical University of Kosice IMEKO Ed., pp. 114-124, 2015.

[35] Cialdea, D., Valorisation strategies for Molise coastal area: archaeological sites and settings of environmental value. In Cultural Tourism and Sustainable Local Development, England, eds P. Nijkamp \& L. Fusco Girard, Ashgate, pp. 181-200, 2009. 